\title{
Post-transfusional hepatitis in neonates hospitalized in a Neonatal Intensive Care Unit
}

\author{
A. Ruiz-Extremera, J. Salmerón ${ }^{1}$, M. L. Rey, C. Torres ${ }^{1}$, P. Muñoz de Rueda ${ }^{1}$, E. Ocete and J. D. Luna \\ Department of Pediatrics. ${ }^{1}$ Department of Gastroenterology. San Cecilio University Hospital. ${ }^{2}$ Department of \\ Biostatistics. School of Medicine. University of Granada. Granada. Spain
}

\begin{abstract}
Objective: to assess the significance of increased serum transaminase levels in neonates admitted to a Neonatal Intensive Care Unit and its relationship with blood transfusion.

Methods: follow-up prospective study of 209 patients; 177 completed follow-up, of whom 129 were transfused and 48 were not; 57 were born after full gestation and 120 were born prematurely. The activity of serum levels of ALT, AST, and GGT was measured monthly up to six months of age, and until six months after the last transfusion. At the end of follow-up, and whenever an increase in serum transaminase levels was detected, the viral agents of hepatitis A, B, C, G, TT, cytomegalovirus, Epstein-Barr, and herpes 1 and 2 , and toxoplasma were studied. Viral serology was also carried out in mothers and in donors when children tested positive.

Results: one hundred twenty nine neonates $(73 \%)$ received $461 \mathrm{U}$ red blood cell transfusions (3.6 $\pm 3 \mathrm{U} /$ patient). ALT levels increased in $54(30.5 \%)$ patients, of whom $46(36 \%)$ were transfused and eight $(17 \%)$ were not $(p<0.05)$. The independent variables were 'infection by $\mathrm{G}$ virus' and 'parenteral nutrition for more than 12 days'; the variable 'transfusion' was close to the limit for statistical significance. Twenty patients (11.3\%) had increased serum ALT levels 2.5 times above the normal value: $18(14 \%)$ were transfused and two $(4 \%)$ were not $(p=0.106)$. Only the $G$ and TT viruses were related with transfusion; patients remained asymptomatic, although most neonates were chronically infected.

Conclusion: follow-up showed that increased serum ALT levels are common among severely ill neonates. Blood transfusions are safe concerning most hepatotropic viruses, but transmission of viruses $\mathrm{G}$ and $\mathrm{TT}$ is possible.
\end{abstract}

Key words: Post-transfusional hepatitis. Newborn babies. Premature infant. Neonatal Intensive Care Unit (NICU). Hepatitis G virus. Hepatitis TT virus.

Financial support: Health Research Fund FIS 95/1524, Junta de Andalucía $\mathrm{N}^{\circ} 84 / 99$, and National Network of Hepatology and Gastoenterology Research (RNIHG)

Recibido: 29-01-04.

Aceptado: 04-05-04.

Correspondencia: Ángeles Ruiz-Extremera. Departamento de Medicina Pediátrica. Hospital Universitario de San Cecilio. Avda. Dr. Olóriz, 16. 18012 Granada. Tel.: 958023 411. Fax: 958240 740. e-mail: arextrem@ugr.es.
Ruiz-Extremera A, Salmerón J, Rey ML, Torres C, Muñoz de Rueda P, Ocete E, Luna JD. Post-transfusional hepatitis in neonates hospitalized in a Neonatal Intensive Care Unit. Rev Esp Enferm Dig 2003; 96: 835-846.

\section{INTRODUCTION}

Therapy for critically ill patients typically includes multiple red blood cell (RBC) transfusions (1). Newborn babies (NBs) admitted to Neonatal Intensive Care Units (NICU) are commonly given transfusions of RBC. In the USA it has been estimated that $80 \%$ of NBs weighing less than $1.500 \mathrm{~g}$ are transfused $(2,3)$. In recent years, guides to clinical practice have been published to standardize criteria for transfusion. Although the administration of human alpha-recombinant erythropoietin (EPO) has allowed decreasing the rate of transfusions, this reduction seems also related to stricter transfusion criteria (2-4). Common indications for neonatal RBC transfusions include volume expansion, cardiorespiratory disease, anemia, growth failure, and apnea. Also used are predictors such as demographic criteria, estimated phlebotomy blood loss, initial hematocrit $(3,4)$, and birth weight $(5)$.

Among NBs weighing less than $1.000 \mathrm{~g}$, an early use of EPO does not reduce the number of transfusions or the number of NBs requiring them (6). It has also been reported (7) that apparently stable anemic NBs show echocardiographic evidence of hemodynamic changes that do not improve after $48 \mathrm{~h}$; this situation is undesirable and potentially dangerous. Another noteworthy fact is the variability of clinical practice among NICUs (8). Although several publications have attempted to clarify indications, the efficacy and safety of clinical practice remains ill-defined (9).

Published studies of post-transfusional hepatitis $(\mathrm{PTH})$ among children are scarce and retrospective $(10,11)$, but studies of reduced PTH have been carried out among adults. Hepatitis $\mathrm{C}$ virus (HCV) was found to be the main 
cause of non-A non-B PTH. However, since anti-HCV testing of blood donors was established as mandatory, PTH has decreased to 0.85 to $3.5 \%$ (12-14), and the possibility of transmitting an infection by HCV is practically nil (15).

Recently, new parenterally transmitted viral agents have been recognized, namely hepatitis $\mathrm{G}$ virus (HGV) and transfusion-transmitted virus (TTV). HGV was detected in $8.6 \%$ of a group of transfused adults, although none of them met criteria for PTH (15), and no hepatic replication of this virus has been shown (16). TTV is transmissible from mother to child through the blood (17), and also via a fecal-oral route (18). It has been detected in patients with non-A to non-G PTH (19).

The objective of the present study was to determine the significance of increased serum transaminase levels among NBs admitted to a NICU, as well as the safety of the transfusions were performed.

\section{METHODS}

From May 1995 to December 1998, a prospective follow-up study was carried out on 209 NBs with previous informed parental consent and the approval of the Hospital Ethics Committee; 177 NBs completed the study, of whom 129 were transfused and 48 were not. Thirty-two were excluded because of loss to follow-up. Of the patients that completed the study, 57 were born at full term and 120 were born prematurely. Fifty-six of the NBs weighed less than $1.500 \mathrm{~g}$ at birth. All were admitted to a NICU and subsequently discharged from hospital.

The follow-up was carried out monthly until the age of six months or until six months after the last transfusion. For the children who presented increased serum ALT levels, follow-up was prolonged with half-yearly visits. The mean follow-up period was $18.7 \pm 9$ months (range, 12 to 48 months). At each check-up serum levels of ALT, AST, and GGT were measured, and at 3 and 6 months, $1 \mathrm{~mL}$ of serum was frozen at $-80^{\circ} \mathrm{C}$. During the last check-up, and whenever an increase in ALT was observed, the following viral agents were studied: hepatitis A virus (HAV), hepatitis B virus (HBV), hepatitis $\mathrm{C}$ virus (HCV), cytomegalovirus (CMV), Epstein-Barr virus (EBV), herpes virus (HV 1 and 2), HGV, and TTV. Due to the possibility of vertical transmission, a virologic study was performed in all mothers and blood donors, and serum samples were frozen.

HGV and TTV were only investigated in mothers if their children tested positive. All units of the packed cells transfused were negative for anti-HCV (ELISA 3), HBsAg, HIV, and syphilis. Donors with increased levels of ALT were rejected. The classical criteria for PTH were applied, namely an increase in serum levels of ALT 2.5 times above normal during a period of 14-180 days posttransfusion, confirmed by a second test (20).

Biochemical parameters were measured using a HITACHI-717 (Boehringer-Mannheim) automatic analyzer. The markers for HAV (anti-HAV IgM), HBV (anti-HBc
IgM and HBsAg), and CMV were studied by ELISA. EBV was determined by indirect immunofluorescence. HCV was tested for anti-HCV by ELISA 3, RIBA3 (Ortho). HCV-RNA was determined in the serum by qualitative RTPCR using the Amplicor HCV Kit (Roche Diagnostics System) according to the manufacturer's instructions.

The analysis of HGV-RNA was carried out by means of amplification and detection of two independent genomic regions: the $5^{\prime}$ non-coding region and the region coding for the NS5a protein. The detection of these two regions was carried out in independent RT-PCR reactions (Boehringer-Mannheim). This method was employed singly for patients with increased levels of ALT, and in pools to study patients with normal levels of transaminases; positive tests were repeated. For the study of antibodies, we used an ELISA (Boehringer-Mannheim) technique, which qualitatively detected anti-HGVE2.

TTV-DNA was extracted from $150 \mu \mathrm{L}$ of serum using the Nucleo Spin Virus Kit (Clontech Laboratories GmbH) and resuspended in $50 \mu \mathrm{L}$ of buffered solution. TTV-DNA was amplified by semi-nested PCR with TTV-specific primers derived from two regions preserved from published sequences (21). For the first PCR, the primers TT6 (sense: 5'ACAGACAGAGGAGAAGGCAA) and TT7 (antisense: 5'TAC CAYTTAGCTCTCATT, with $\mathrm{Y}=\mathrm{C}$ and T) (22) were used to amplify a product of $329 \mathrm{bp}$. After electrophoresis on agarose gel, samples producing a single band of $267 \mathrm{bp}$ (the expected size for the amplified TTVDNA fragment) were considered positive.

\section{Statistical method}

For qualitative variables, the statistical $\chi^{2}$ or two-tailed exact Fisher's test was used, and the odds ratio (Ô) and confidence intervals $(\mathrm{CI})$ were estimated. For the analysis of quantitative variables, a Wilcoxon's test for independent samples was carried out. In all tests, a statistical significance level of $95 \%$ was taken. Exact logistic regression analysis (Logxact) was used to assess the independent effects of significant variables in univariate analysis. The final models were built in a three-step manner: in the first one, individual effects were considered (model 0); in the second step, the whole set of variables was used (model I), and in the third step (model II), only significant variables in the previous model were considered.

\section{RESULTS}

The gestation period was $34.4 \pm 4.5$ weeks (24-43 weeks), and the weight at birth was $2195 \pm 944 \mathrm{~g}$ (range, $550-4350 \mathrm{~g})$. One hundred fifty nine $159 \mathrm{NBs}(89 \%)$ were treated with antibiotics, $109(62 \%)$ received machine-assisted ventilation lasting an average of $13 \pm 15$ days (1-80 days), $82(46 \%)$ were treated with vasoactive drugs, and $74(42 \%)$ received parenteral nutrition for an average of 
$25 \pm 20$ days (2-99 days). Mean stay at the NICU was $28 \pm$ 28 days (range, 2-180 days), and total hospitalization period was 38.5 \pm 31 days (range, 5-195 days). Of the $177 \mathrm{NBs,}$ $129(73 \%)$ needed transfusion and received 461 units (U), with an average of $3.6 \pm 3 \mathrm{U}$ (1-21 U per patient).

\section{Patients who had increased serum ALT levels}

ALT levels were higher in $54(30.5 \%)$ patients, 46 $(36 \%)$ of whom were transfused, and eight (17\%) were not transfused $(\mathrm{p}<0.05)$. Table I and II show the results of the univariate and multivariate analysis, respectively.

\section{Patients who had serum ALT levels 2.5 times above normal values}

Only 20 (11.3\%) children had ALT 2.5 times above the normal value; $14 \%$ of them were transfused and $4 \%$ were not $(p=0.106)$. Table III shows the results of the univariate analysis, and table IV those of the multivariate analysis.

\section{Patients who had an increase in serum AST and GGT levels}

In all, 128 patients $(72 \%)$ had an increase in serum AST levels $(81.7 \pm 128 \mathrm{U} / \mathrm{L} ; 95 \%$ CI 59-104 U/L). Of these, $93(73 \%)$ were transfused and $36(73 \%)$ were not.

Serum GGT levels were increased in $64(36 \%)$ patients $(136 \pm 146 \mathrm{U} / \mathrm{L} ; 95 \%$ CI 95-176 U/L). This increase correlated with a shorter gestation period $(\mathrm{p}<$ $0.01)$, a low weight at birth $(\mathrm{p}<0.05)$, an increased serum ALT levels ( $p<0.01)$, PTH $(\mathrm{p}<0.05)$, and, at the limit of statistical significance, with transfusion $(\mathrm{p}=$ $0.065)$ and parental nutrition $(\mathrm{p}=0.096)$.

\section{Viral study}

We did not observe any patient with HAV, HBV, HCV, $\mathrm{HV}$ or EBV infection. One child who was not transfused had infection by CMV at 5 months of age, with serum ALT levels of $75 \mathrm{U} / \mathrm{L}$ that persisted for one month. A study of the mother proved negative for CMV.

HGV was detected in 15/177 (9\%) neonates; 14 were HGV-RNA-positive and one was considered to be infected in spite of being HGV-RNA-negative, since seroconversion to anti-HGV E2 antibody occurred during the course of follow-up. Of these neonates, 11/129 (9\%) had been transfused and 4/48 (8\%) had not. Differences were not statistically significant.

Figure 1 shows epidemiological features of $\mathrm{HGV}$ infection among transfused neonates, who had nine cases of parenteral infection and two of vertical infection. The rate of $\mathrm{HGV}$ infection by transfusion was 7\% (95\% CI, 3$13 \%)$. Patients with post-transfusion $\mathrm{HGV}$ infection received an average of $6 \pm 5 \mathrm{U}$ (range, 1-14 U) concentrated RBC. The transfused and HGV-negative patients received $3 \pm 3 \mathrm{U}$ (range, 1-22 U). Difference between means was not statistically significant. The risk of $\mathrm{HGV}$ transmission per transfused unit of RBC was $1.96 \%(95 \%$ CI, $1-3.8 \%)$. The mothers of the four non-transfused HGV-RNA-positive NBs were also HGV-RNA-positive (vertical transmission).

An anti-HGV E2 study was carried out in all NBs, and was found to be negative in all of them, except in one who

Table I. Characteristics of neonates, therapeutic intervention, and serum ALT levels

\begin{tabular}{lccc}
\hline & Increased ALT $(n=54)$ & Normal ALT $(n=123)$ & $p$ \\
\hline Sex: male & $30(55.5)$ & $68(55.2)$ & $34.5 \pm 4.6$ \\
Gestational age (weeks) & $34.2 \pm 4.3$ & $2171 \pm 918$ & 0.644 \\
Birth weight (g) & $2249 \pm 1007$ & $37(30)$ & 0.626 \\
Weight $\leq 1500 \mathrm{~g}$ & $19(35)$ & $83(67)$ & 0.853 \\
Transfusion & $46(85)$ & $2.05 \pm 2.7$ & 0.017 \\
No. of transfusions & $3.85 \pm 4.6$ & $2.08 \pm 2.7$ & 0.009 \\
No. of donors & $3.96 \pm 4.6$ & $47(38)$ & 0.007 \\
Parenteral nutrition & $27(50)$ & $7.6 \pm 14$ & 0.185 \\
Days of parenteral nutrition & $17.3 \pm 23.3$ & $72(58)$ & 0.006 \\
Mechanically-assisted ventilation & $37(68)$ & $6.2 \pm 12$ & 0.242 \\
Days of mechanically-assisted ventilation & $12.1 \pm 15$ & $108(88)$ & 0.016 \\
Antibiotics & $51(94)$ & $25.1 \pm 22$ & 0.279 \\
Days in NICU & $34.7 \pm 36$ & $35.6 \pm 26$ & 0.079 \\
Days in hospital & $45.2 \pm 40$ & $1(0.8)$ & 0.110 \\
Positive VHG & $14(30)$ & $23(19)$ & 0.0001 \\
Positive VTT & $16(30)$ & 0.782 \\
\hline
\end{tabular}

Quantitative variables are expressed as mean \pm standard deviation, and qualitative variables as number of infants and percentage (\%). 
Table II. Logistic regression of neonates with increased ALT

\begin{tabular}{|c|c|c|c|c|c|c|}
\hline & \multicolumn{2}{|c|}{ Model 0} & \multicolumn{2}{|c|}{ Model I } & \multicolumn{2}{|c|}{ Model II } \\
\hline & $\hat{o}$ & $\mathrm{Cl}$ & $\hat{o}$ & $\mathrm{Cl}$ & $\hat{o}$ & $\mathrm{Cl}$ \\
\hline Transfusion & 2.77 & $1.20-6.42$ & 2.44 & $0.88-6.77$ & 2.3 & $0.83-6.20$ \\
\hline$>9$ days mech.-assisted ventilation & 2.84 & $1.41-5.73$ & 1.74 & $0.49-6.14$ & & \\
\hline$>12$ days parenteral nutrition & 2.91 & $1.45-5.83$ & 2.06 & $0.54-7.9$ & 2.3 & $1.05-5.18$ \\
\hline > 39 days NICU & 1.78 & $0.88-3.61$ & 0.81 & $0.21-3.05$ & & \\
\hline Positive VHG & 42.7 & $5.44-334.8$ & 45.8 & $5.59-376$ & 46 & $5.64-376$ \\
\hline & & 76.671 & & & & \\
\hline
\end{tabular}

Comments: Model 0 shows the risk (ô) of increased serum ALT levels, and the corresponding confidence intervals. Model I shows that variables were strongly interrelated, and VHG infection was a statistically significant variable [ô = 45.8 (5.59-37.6]. Finally, model II shows that the only independent variables were those of HGV infection (the risk of increased serum ALT levels was 46 times greater than in patients with negative HGV) and 'parenteral nutritional greater than 12 days'. The variable 'transfusion' was at the limit of statistical significance.

Table III. Characteristics of neonates, therapeutic intervention, and serum levels of ALT among patients presenting with serum levels of ALT 2.5 times above the normal level: criterion of post-transfusion hepatitis (PTH)

\begin{tabular}{lccc}
\hline & PTH criterion $(n=20)$ & No PTH criterion $(n=157)$ & $p$ \\
\hline Sex: male & $10(50)$ & $88(56)$ & 0.639 \\
Gestational age (weeks) & $32.5 \pm 4.8$ & $34.7 \pm 4.5$ & 0.044 \\
Birth weight (g) & $1917 \pm 1002$ & $2230 \pm 930$ & 0.163 \\
Weight $\leq 1500 \mathrm{~g}$ & $11(55)$ & $45(29)$ & 0.018 \\
Transfusion & $18(90)$ & $2.2 \pm 2.8$ & 0.106 \\
No. of transfusions & $5.85 \pm 6$ & $2.24 \pm 3$ & 0.012 \\
No. of donors & $5.9 \pm 5.7$ & $61(39)$ & 0.011 \\
Parenteral nutrition & $13(65)$ & $9.18 \pm 17$ & 0.031 \\
Days of parenteral nutrition & $21.7 \pm 22.6$ & $93(59)$ & 0.026 \\
Mechanically-assisted ventilation & $16(80)$ & $6.75 \pm 12$ & 0.089 \\
Days of mechanically-assisted ventilation & $18.35 \pm 19.5$ & $140(89)$ & 0.017 \\
Antibiotics & $19(95)$ & $25.7 \pm 25.8$ & 0.698 \\
Days in NICU & $45.9 \pm 37$ & $36.1 \pm 29.4$ & 0.027 \\
Days in hospital & $57.4 \pm 41$ & $10(6)$ & 0.036 \\
Positive VHG & $5(25)$ & $31 / 107(29)$ & 0.016 \\
Positive VTT & $8 / 20(40)$ & 0.918 \\
\hline
\end{tabular}

Quantitative variables are expressed as mean \pm standard deviation, and qualitative variables as number of infants and percentage (\%).

was positive at 6 months and negative three months later. The mother of this NB showed anti-HGV E2 antibody positive, therefore it was considered that the positive antibody in this child resulted from a passive transmission.

The clinical course of the HGV infection was mild (Fig. 2). Fourteen NBs (93\%) presented increased ALT, but only in five $(33 \%)$, serum ALT levels were higher than 2.5-fold above the normal value. The maximum ALT level recorded was $78 \pm 46 \mathrm{U} / \mathrm{L}$, and the mean duration was $3 \pm 2$ months. Only four patients were virus-free at 18,36 , and 48 months, and 1 neonate sero-converted to anti-HGV E2 antibody. The remaining 11 patients remained HGV-RNApositive, but ALT was normal.

TTV-DNA was studied in 127 neonates, of whom was positive in $39(31 \%)$. Of these, 36/109 (33\%) had been transfused and 3/16 (17\%) had not been transfused. This difference was not statistically significant. In the transfused group, there were five cases of vertical transmis- sion, since mothers were also positive. The remaining mothers tested negative and parenteral transmission was considered most likely, although serum from the donors was not available. The mothers of three cases in the nontransfused group were TTV-DNA-positive; therefore, a vertical transmission was most likely. In seven cases, there was a co-infection by HGV.

The clinical course of the TTV infection was asymptomatic. Sixteen neonates showed increased serum ALT levels, and six of them were co-infected with the HGV. Of these, eight $(50 \%)$ had an increase in serum ALT levels 2.5 times above the normal value; three of these were co-infected with the HGV. The maximum level recorded for ALT was $87 \pm 81 \mathrm{U} / \mathrm{L}$, and the mean duration was $4 \pm 3$ months. Only two children had cleared up the virus at 6 and 18 months, the others children remaining positive, although with normal serum ALT levels. 
Table IV. Logistic regression of patients with serum levels of ALT increased 2.0-2.5 times normal levels (PTH criterion)

\begin{tabular}{|c|c|c|c|c|c|c|}
\hline & \multicolumn{2}{|c|}{ Model 0} & \multicolumn{2}{|c|}{ Model I } & \multicolumn{2}{|c|}{ Model II } \\
\hline & $\hat{o}$ & $\mathrm{Cl}$ & $\hat{o}$ & $\mathrm{Cl}$ & $\hat{O}$ & $\mathrm{Cl}$ \\
\hline Transfusion & 3.73 & $0.83-16.73$ & & & & \\
\hline$>2$ transfusions & 3.04 & $1.18-7.84$ & & & & \\
\hline$>2$ donors & 3.51 & $1.35-9.14$ & 0.87 & $0.18-4.35$ & & \\
\hline Parenteral & 2.92 & $1.10-7.73$ & & & & \\
\hline$>12$ days parenteral & 5.04 & $1.91-13.2$ & 0.93 & $0.11-7.69$ & & \\
\hline Mechanical ventilation & 2.75 & $0.88-8.61$ & & & & \\
\hline > 9 days mech. vent. & 5.42 & $2.06-14.33$ & 2.26 & $0.56-9.10$ & 2.9 & $0.88-9.28$ \\
\hline Positive VHG & 4.9 & $1.48-16.23$ & 3.65 & $0.93-14.3$ & 4.2 & $1.15-15.34^{*}$ \\
\hline Birth weight $<1500 \mathrm{~g}$ & 3.04 & $1.18-7.84$ & 1.72 & $0.48-6.13$ & & \\
\hline > 39 days in NICU & 4.42 & $1.69-11.54$ & 1.93 & $0.39-9.6$ & & \\
\hline$>54$ days in hospital & 3.24 & $1.25-8.39$ & & & & \\
\hline
\end{tabular}

Comments: Model 0 shows the risk (ô) of serum levels of ALT 2.5 times above normal levels, together with the corresponding confidence intervals. Strongly interrelated variables have been removed from model I (none of which were statistically significant), although HGV infection was close to the limit for statistical significance [ô $=3.65$ ( 0.93 - 14.34)]. Model II shows that the only independent variable was HGV infection.

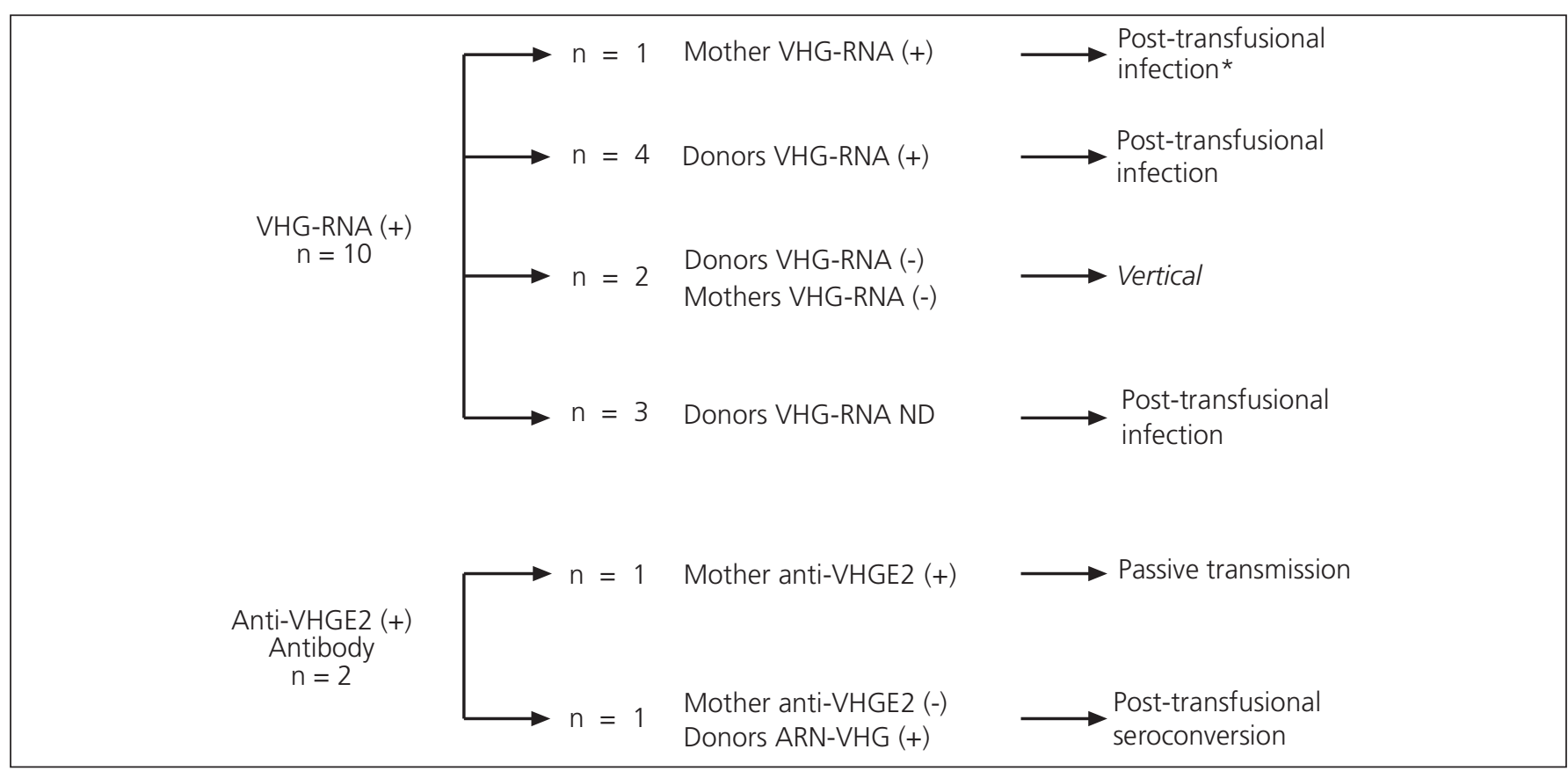

Fig. 1.- Epidemiology of HGV infection in transfused neonates. *Monoamniotic monochorial twins, both transfused, HGV(+) mother, and only when the child tested positive was the donor HGV (+).

Epidemiología de la infección VHG en neonatos transfundidos. *Gemelos monocoriales monoamnióticos, ambos transfundidos, madre VHG (+) y sólo en el niño positivo el donante fue VHG (+).

\section{Serologic study of mothers}

Serologic studies carried out in mothers showed that $76(47 \%)$ had anti-CMV IgG antibody, $46(28 \%)$ antiHAV IgG, 39 (25\%) anti-EBV IgG, 27 (17\%) anti-HVs IgG, 11 (7\%) anti-toxoplasmca IgG, 7 (4\%) anti-HBs, 2 (1\%) anti-EBV IgM and one (0.6\%) anti-CMV IgM antibodies. In the latter two cases, no repercussions on the children were observed.

\section{DISCUSSION}

To date, the real prevalence of post-transfusional pathology among premature and full-term neonates remains unknown. For this reason, we analyzed factors related with increased levels in serum ALT levels in these patients. Patients who were most severely ill and those with the lowest weight at birth required a longer period of hospitalization in the NICU, although not all of them 


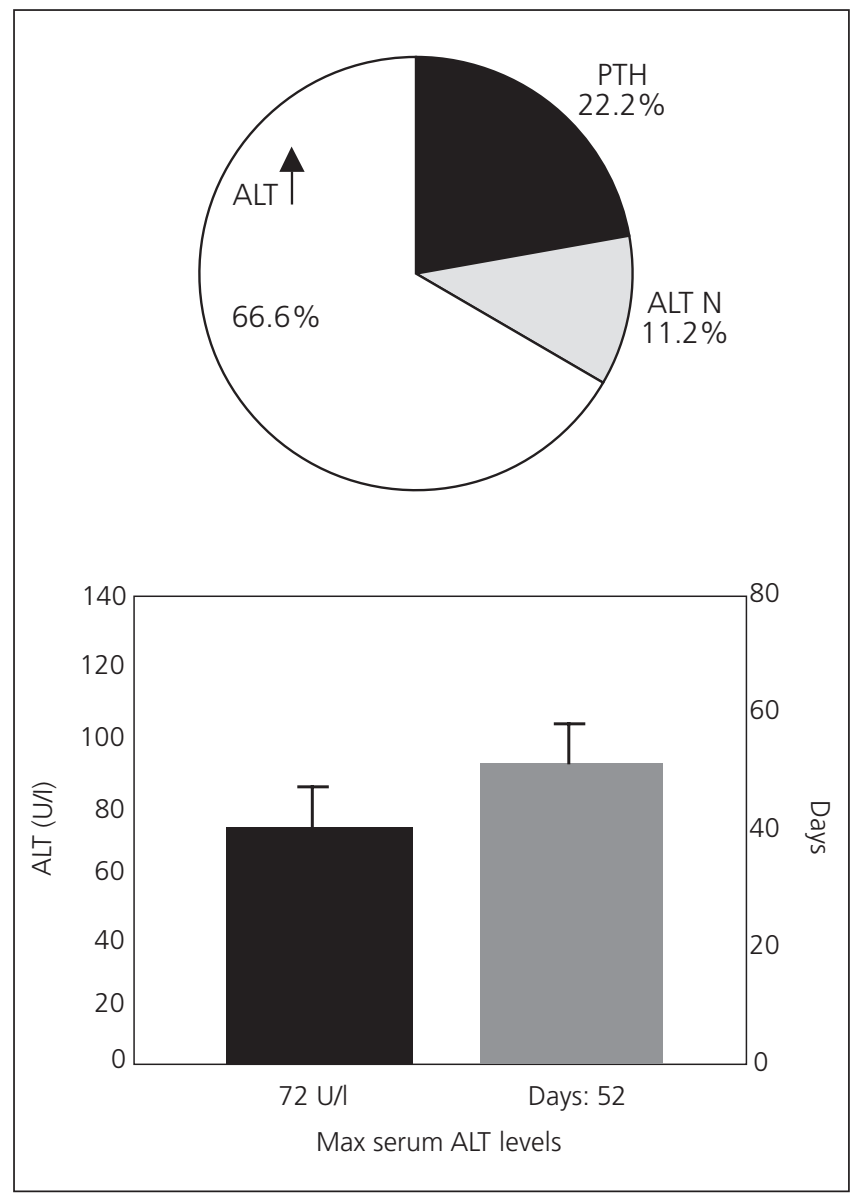

Fig. 2.- Clinical evolution of HGV (+) neonates.

Evolución clínica de los niños VHG (+).

underwent a higher number of therapeutic procedures, including transfusion.

Seventy percent of neonates admitted to the NICU had no increase in serum ALT levels. Neither weight nor gestational age were related with increased serum levels of ALT. Transfusion, number of units transfused, duration of hospitalization period in the NICU, duration of mechanically-assisted ventilation, and duration of parenteral nutrition were all related with increased ALT levels. Most of the severely ill neonates received all these interventions; differences between them concerned the duration of such interventions; thus, variables are interrelated each other. In contrast, $\mathrm{HGV}$ infection, duration of parenteral nutrition, and the fact of having received transfusions are independent variables within the logistic regression analysis. Póstuma, et al. (23) described a transitory increase in serum levels of alkaline phosphatase and ALT in 34\% of NBs after 4-6 weeks of parenteral nutrition. Other authors have reported the presence of liver complications in low-weight, premature NBs (24-26). In our study, increased serum ALT levels were not related with weight or gestation period.

Hepatitis among adults has been widely studied, and it is known that it represents a risk factor of post-trans- fusional disease. In the present study, $14 \%$ of the transfused neonates, and $4 \%$ of the non-transfused neonates presented an increase in the serum ALT levels 2.5 times above the normal value. HGV was responsible for only five cases, and in three of them, a TTV co-infection was also present. This means that increased serum ALT levels results from other factors, which may be related with the main illness that led to the admission into the NICU or to other unidentified transfusion-transmitted viruses (27). Increased serum levels of AST was also common, although less specific. Note the number of patients who presented increased serum GGT levels; this was more frequent among low-birth-weight neonates, and it is likely related to a certain degree of cholestasis.

A surprising finding is the high prevalence of the TTV infection $(31 \%)$. In Spain, the prevalence of this infection among healthy blood donors is 14 and $76 \%$ among patients with hemophilia (28). Vertical transmission of HGV and TTV is important and responsible for infection in non-transfused and some transfused neonates. Accordingly, it is essential to study mothers and blood donors in order to interpret the importance of transfusion as the factor responsible for transmission of these viruses. Some authors have reported the vertical transmission of HGV and TTV infections $(29,30)$ and appears to be more frequent than that of $\mathrm{HCV}$ infection (31).

In conclusion, this study shows how important it is to monitor levels of serum ALT levels in NBs hospitalized in NICUs, as such patients are already subject to multiple factors that may give rise to liver disease. We should also underline the importance of virologic studies, not only of NBs but also of mothers and blood donors. Although HGV has not been clearly related with liver lesions in adults, in NBs it may cause increased levels of serum levels of ALT. Finally, it should be underlined that transfusions are safe regarding most viruses, but the transmission of new agents such as HGV and VTT, whose pathogenicity is very low, is possible.

\section{REFERENCES}

1. Corwin HL, Gettinger A, Pearl RG, Fink MP, Levi MM, Shapiro MJ, et al. Efficacy of recombinant human erythropoietin in critically ill patients: A randomized controlled trial. JAMA 2002; 288: 2827-35.

2. Strauss RG. Erythropoietin and neonatal anemia. N Engl J Med 1994; 330: $1227-8$.

3. Shannon KM, Keith JF, Mentzer WC, Ehrenkranz RA, Brown MS, Widness JA, et al. Recombinant human erithropoietin stimulates erythropoiesis and reduces erythrcyte transfusions in very low birth weight preterm infants. Pediatrics 1995; 95: 1-10.

4. Strauss RG. Practical issues in neonatal transfusion practice. AJCP 1997; 107 (4) (Supl. 1): S57-63.

5. Maier RF, Obladen M, Messinger D, Wardrop C. Factors related to transfusion in very low birthweight infants treated with erythropoietin. Arch Dis Child Fetal Neonatal Ed 1996; 74: F182-6.

6. Ohls RK, Ehrenkranz RA, Wright LL, Lemons JA, Korones SB, Stoll BJ, et al. Effects of early erythropoietin therapy on the transfusion requirements of preterm infants below 1250 grams birth weight: A multicenter, randomized, controlled trial. Pediatrics 2001; 108: 934-42. 
7. Alkalay AL, Galvis S, Ferry DA, Simmons CF, Krueger RC. Hemodynamic changes in anemic premature infants: Are we allowing the hematocrits to fall too low? Pediatrics 2003; 112: 838-45.

8. Ringer SA, Richardson DK, Sacher RA, Keszler M, Churchill WH. Variations in transfusion practice in Neonatal Intensive Care. Pediatrics 1998; 101: 194-200.

9. Editorials. Practice variation: Implications for neonatal red blood cell transfusions. J Pediatr 1998; 133: 589-90.

10. Blajchman MA, Sheridan D, Rawls WE. Risks associated with blood transfusion in newborn infants. Clin Perinatol 1984; 2: 403-15.

11. Keller KM, Wirth S. Hepatitis C virus (HCV). Low infection rate in premature and full-term neonates following multiple transfusions. Monatsschr Kinderheilkd 1992; 140 (2): 108-12.

12. González A, Esteban JI, Madoz P, Viladomiu L, Genesca J, Muñiz E, et al. Efficacy of screening donors for antibodies to the hepatitis $\mathrm{C}$ virus to prevent transfusion-associated hepatitis: final report of a prospective trial. $\mathrm{He}-$ patology 1995; 22: 439-45.

13. Salmerón J, Gila A, Oyonarte S, Palacios A, Pérez Ruiz M, Fernández Montoya A, et al. Estudio prospectivo de la incidencia de hepatitis postranfusional después de la exclusión de los donantes anti-VHC ELISA 2 positivos. Med Clin 1995; 105: 641-4.

14. Barrera JM, Bruguera M, González M, Gálvez A, Castillo R, Rodés J. Eficacia de la exclusión de donantes anti-VHC positivo por ELISA 2 en la prevención de la hepatitis postransfusional. Gastroenterol Hepatol 1996; 19: 240-2

15. Salmerón J, Carmona I, Torres C, Muñoz de Rueda P, Gila A, Ruiz-Extremera A. Estudio retrospectivo de la incidencia de infección por el virus de la hepatitis G en los pacientes transfundidos. Med Clin 1999; 112: 40911.

16. Torres C, Muñoz de Rueda P, Ruiz-Extremera A, Quintero D, Palacios A Salmerón J. Genomic and antigenomic chains of hepatitis $C$ virus and hepatitis $\mathrm{G}$ virus in serum, liver and peripheral blood mononuclear cells. Rev Esp Enferm Dig 2002; 94: 659-63.

17. Sugiyama K, Goto K, Ando T, Mizutani F, Terabe K, Kawabe Y, et al. Route of TT Virus infection in children. J Med Virol 1999; 59: 204-7.

18. Okamoto H, Akahane Y, Ukita M, Fukuda M, Tsuda F, Miyakawa Y, et al Fecal excretion of a nonenveloped DNA virus (TTV) associated with posttransfusion non-A-G hepatitis. J Med Virol 1998; 56 (2): 128-32.

19. Nishizawa T, Okamoto H, Konishi K, Yoshizawa H, MiyaKawa Y, Mayumi M. A novel DNA virus (TTV) associated with elevated transaminase levels in posttransfusion hepatitis of unknown etiology. Biochem Biophys Res Commun 1997; 241: 92-7.

20. Esteban JI, González A, Hernández JM, Viladomiu L, Sánchez C, López-Talavera JC, et al. Evaluation of antibodies to hepatitis C virus in a study of transfusion associated hepatitis. N Engl J Med 1990; 323: 1107-12.

21. Okamoto H, Nishizawa T, Kato N, Ukita M, Ikeda H, Lizuka H, et al. Molecular cloning and characterization of a novel DNA virus (TTV) associated with posttransfusion hepatitis of unknown etiology. Hepatology Research 1998; 10: 1-16.

22. Höhne M, Berg T, Müller AR, Schreier E. Detection of sequeences of TT virus, a novel DNA virus, in german patients. J General Virology 1998; 79: $1-4$.

23. Postuma R, Trevenen CL. Liver disease in infants receiving total parenteral nutrition. Pediatrics 1979; 63: 110-5.

24. Bell RL, Ferry GD, Smith EO, Shulman RJ, Christensen BL, Labarthe DR, Wills CA. Total parenteral nutricion-related cholestasis in infants. JPEN 1988; 2: 602-6.

25. Howell RR. The diagnostic value of serum enzyme measurements. J Pediatr 1996; 68: 121-34.

26. Brown MR, Thunberg BJ, Goloub L, Maniscalo WM, Cox C, Shapiro DL. Decresed cholestasis with enteral instead of intravenous protein in the very low-birth weight infants. J Pediatr Gastroenterol Nutr 1989; 9: 21-7.

27. Tanaka Y, Primi E, Wang RY, Umemura T, Yeo AE, Mizokami M, et al Genomid and molecular evolutionary analysis of a newly identified infectious agent (SEN virus) and its relationship to the TT virus family. J Infect Dis 2001; 183: 359-67.

28. Puig-Basagoiti F, Cabana M, Guilera M, Giménez-Barcons M, Sirera G, Tural C, et al. Prevalence and route of transmission of infection with a novel DNA virus (TTV), hepatitis $\mathrm{C}$ virus, and hepatitis $\mathrm{G}$ virus in patients infected with HIV. J Acquir Immune Defic Syndr 2000; 23 (1): 89-94.

29. Feucht HH, Zölner B, Polywka S, Laufs R. Vertical transmision of hepatitis G. Lancet 1996; 347: 615-6.

30. Davidson F, MacDonald D, Mokili JL, Prescott LE, Graham S, Simmonds $\mathrm{P}$, et al. Early acquisition of TT virus (TTV) in an area endemic for TTV infection. J Infect Dis 1999; 179 (5): 1070-6.

31. Ruiz-Extremera A, Salmerón J, Torres C, De Rueda PM, Giménez F, Robles $\mathrm{C}$, et al. Follow-up of transmission of hepatitis $\mathrm{C}$ to babies of human immunodeficiency virus-negative women: the role of breast-feeding in transmission. Pediatr Infect Dis J 2000; 19 (6): 511-6.

\title{
Hepatitis post-transfusional en neonatos encamados en una Unidad de Cuidados Intensivos Neonatal
}

\author{
A. Ruiz-Extremera, J. Salmerón ${ }^{1}$, M. L. Rey, C. Torres ${ }^{1}$, P. Muñoz de Rueda ${ }^{1}$, E. Ocete y J.D. Luna ${ }^{2}$ \\ Departamento de Pediatría. ${ }^{2}$ Departamento de Digestivo. Hospital Universitario San Cecilio. ${ }^{2}$ Departamento de \\ Bioestadística. Facultad de Medicina. Universidad de Granada. Granada
}

\section{RESUMEN}

Objetivo: estudiar la importancia y significado del aumento de transaminasas en neonatos que ingresaron en una Unidad de Cuidados Intensivos Neonatales y su relación con la transfusión sanguínea.

Proyecto financiado: Fondo de Investigaciones Sanitarias 95/1524, Junta de Andalucía, $N^{\circ} 84 / 99$ y Red Nacional de Investigación en Hepatología y Gastroenterología (RNIHG)
Métodos: seguimiento prospectivo de 209 pacientes de los cuales 177 completaron el seguimiento: 129 transfundidos y 48 no transfundidos (57 nacidos a término y 120 prematuros). Se determinaron la ALT, AST y GGT mensualmente hasta los seis meses de edad y hasta los seis meses de la última transfusión. Al final del seguimiento y cuando había un aumento de transaminasas se investigó el virus de la hepatitis A, B, C, G, TT, citomegalovirus, Epstein-Barr, herpes 1-2 y toxoplasma. La serología viral también se estudió en todas las madres y en los niños positivos en sus donantes. 
Resultados: ciento veintinueve neonatos $(73 \%)$ recibieron $461 \mathrm{U} /$ concentrados-hematíes (3,6 $23 \mathrm{U} /$ paciente). Cincuenta y cuatro pacientes $(30,5 \%)$ presentaron un aumento de ALT, 46 (36\%) transfundidos y $8(17 \%)$ no transfundidos ( $<<0,05)$. Las variables independientes asociadas con este aumento de las transaminasas fueron: la infección con el virus $G$, la nutrición parenteral durante más de 12 días y, con casi significación estadística, la transfusión. Veinte pacientes (11,3\%) tenían un aumento de ALT superior a 2,5 veces el valor normal: 18 (14\%) transfundidos, 2 $(4 \%)$ no transfundidos $(p=0,106)$. Sólo el virus $G$ y el virus TT se relacionaron con la transfusión; el curso clínico fue asintomático, aunque la mayoría quedaron crónicamente infectados.

Conclusión: en el seguimiento de los neonatos graves, el aumento de las transaminasas es frecuente. Las transfusiones son seguras para la mayoría de los virus hepatotropos, pero es posible la transmisión de los virus G y TT.

Palabras clave: Hepatitis postransfusional. Recién nacidos. Recién nacidos prematuros. Unidad de Cuidados Intensivos Neonatales (UCIN). Virus de la hepatitis G. Virus de la hepatitis TT.

\section{INTRODUCCIÓN}

Los pacientes críticamente enfermos requieren a menudo hemoderivados como terapia (1). Los recién nacidos (RN) ingresados en Unidades de Cuidados Intensivos Neonatales (UCIN) reciben sobre todo concentrados de hematíes. En EE.UU. se estima que el $80 \%$ de los nacidos con menos de $1.500 \mathrm{~g}$ son transfundidos $(2,3)$. En los últimos años han aparecido guías de práctica clínica para homogeneizar las indicaciones de transfusión. Aunque la administración de eritropoyetina alfa recombinante humana (EPO) ha permitido disminuir esta práctica, parece que esta disminución está relacionada con unos criterios de transfusión más estrictos (24). Las indicaciones para la administración de concentrados de hematíes a neonatos incluyen: la expansión de volumen, la enfermedad cardiorrespiratoria, anemia, falta de crecimiento y apneas. También se han utilizado como predictores los criterios demográficos, las pérdidas por flebotomías, el hematocrito inicial $(3,4)$ y el peso al nacimiento $(5)$.

En los nacidos con menos de $1.000 \mathrm{~g} \mathrm{(6)}$ de peso, el uso de EPO precoz no disminuye el número de transfusiones ni el de niños que la precisaron. También se ha comunicado (7) que los neonatos anémicos aparentemente estables, presentan alteraciones hemodinámicas ecocardiográficas, que no mejoran en las 48 horas que siguen a la transfusión, situación indeseable y potencialmente peligrosa. Otro hecho de interés es la variabilidad en la práctica clínica de unas UCIN a otras (8) y aunque se suceden las publicaciones intentando clarificar las indicaciones, la eficacia y seguridad de la misma no está bien definida (9).

Los estudios de hepatitis postransfusional (HPT) en niños son escasos y retrospectivos $(10,11)$. Por las publicaciones en adultos se conoce la reducción de la HPT. El virus de la hepatitis $\mathrm{C}$ (VHC) fue el principal causante de la HPT noA-noB, sin embargo, desde que se impuso la obligatoriedad de determinar los anti-VHC a los donantes de sangre, la tasa de HPT oscila entre $0,85-3,5 \%(12-14)$ y las posibilidades actuales de transmitir una infección por el VHC son prácticamente nulas (15).

Recientemente se han reconocido nuevos agentes virales de transmisión parenteral, concretamente, el virus de la hepatitis $\mathrm{G}$ (VHG) y el virus transmitido por la transfusión (VTT). El VHG se detectó en el 8,6\% de un grupo de adultos transfundidos, aunque ninguno de ellos presentó criterios de HPT (15) y en ningún caso se ha demostrado replicación hepática de este virus (16). El VTT es un virus transmisible por la sangre, de la madre al hijo (17) y también por vía fecal-oral (18) y ha sido detectado en pacientes con HPT noA a noG (19).

El objetivo del estudio fue conocer la importancia y el significado del aumento de las transaminasas en niños que precisaron ingreso en una UCIN en el periodo neonatal y la seguridad de la transfusión.

\section{MÉTODOS}

Desde mayo de 1995 hasta diciembre de 1998 se incluyeron $209 \mathrm{RN}$, en un estudio de seguimiento prospectivo, previo consentimiento informado de los padres y la aprobación del Comité de Ética del Hospital. Completaron el estudio 177 RN (129 transfundidos y 48 no transfundidos), 32 fueron excluidos por pérdida del seguimiento. Del total de pacientes que completaron el estudio, 57 nacieron a término y 120 fueron prematuros, 56 de ellos con un peso inferior a los $1.500 \mathrm{~g}$. Todos precisaron ingreso en UCIN y fueron dados de alta del hospital.

El seguimiento fue mensual hasta los seis meses de vida o seis meses después de la última transfusión. En los niños con aumento de ALT se prolongó el seguimiento con visitas semestrales, la media del seguimiento fue de 18,7 \pm 9 (1248) meses. En cada revisión se determinó la ALT, AST, GGT. En el tercero y sexto mes se congeló $\left(-80^{\circ} \mathrm{C}\right)$ un $\mathrm{ml}$ de suero. En la última revisión y en los aumentos de ALT se investigó el virus de la hepatitis A (VHA), hepatitis B (VHB), VHC, citomegalovirus (CMV), Epstein-Barr (VEB), herpes 1-2, VHG y VTT. En todas las madres, ante la posibilidad de una transmisión vertical, y en los donantes se realizó el estudio virológico y se congeló el suero.

El VHG y VTT se determinó sólo cuando el niño era positivo. Los productos transfundidos fueron negativos para anti-VHC (ELISA 3), HBsAg, VIH, sífilis y se excluyeron a los donantes con ALT aumentada. Se consideró que reunían criterios de HPT a los pacientes que presentaban aumentos de la ALT 2,5 veces el valor máximo normal entre los 14-180 días tras la transfusión, comprobado en una segunda determinación (20).

Los parámetros bioquímicos se determinaron con el analizador automático HITACHI-717 (Boehringer-Mannheim). Los marcadores del VHA (anti-VHAIgM), VHB (anti-HBcIgM, HBsAg) y CMV se estudiaron mediante ELISA. El VEB por inmunofluorescencia indirecta. El VHC, mediante ELISA 3, RIBA3 (Ortho), el ARN VHC se determinó en suero mediante RT-PCR cualitativa, con el 
Kit Amplicor HCV (Roche Diagnostics System), siguiendo las instrucciones de uso.

El análisis del ARN-VHG se realizó por amplificación y detección de dos regiones genómicas independientes: la 5' no codificante $\left(5^{\prime} \mathrm{NCR}\right)$ y la que codifica la proteína NS5a. La detección de estas dos regiones se llevó a cabo en reacciones independientes de RT-PCR (Boehringer Mannheim). Este método se empleó de forma aislada para los pacientes con ALT aumentada y de forma agrupada (pools) para estudiar a los pacientes con transaminasas normales y en los casos positivos se repitió de forma aislada. Para el estudio de los anticuerpos se usó una técnica de enzimo-inmunoanálisis (ELISA-VHG, Boehringer Mannheim), que detecta cualitativamente anti-VHGE2.

Para la determinación del VTT, la extracción del ADN se realizó de $150 \mu \mathrm{l}$ de suero usando Nucleo Spin Virus Kit (Clontech Laboratories $\mathrm{GmbH}$ ) y resuspendido en $50 \mu \mathrm{lde}$ solución buffer. El ADN VTT fue amplificado por seminested PCR con cebador específico VTT derivados de dos regiones conservadas de las secuencias publicadas por Okamoto y cols. (21). Para la primera PCR, se usaron los cebadores TT6 (sense: 5'ACAGACAGAGGAGAAGGCAA) y TT7 (antisense: 5'TAC CAYTTAGCTCTCATT, con Y=C y T) (22) para la amplificación del producto de 329 bp. Tras la separación electroforética en gel de agarosa, los sueros que produjeron una sola banda de 267 bp (el tamaño previsto para el fragmento amplificado de ADN-VTT) fueron considerados como positivos.

\section{Método estadístico}

Para las variables cualitativas se usó el test estadístico $\chi^{2}$ o el test exacto de Fisher en la unión de dos colas, esti- mando la "odds ratio" e intervalo de confianza. Para las variables cuantitativas se aplicó el test de Wilcoxon. En todos los tests e intervalos de confianza se consideró un nivel de significación estadística del 95\%. Para conocer el efecto independiente de las variables significativas en el análisis univariante se usó la regresión logística exacta. El modelo final fue construido en tres fases, en la primera fue considerado el efecto individual (modelo 0), en la segunda se usaron todas las variable (modelo I) y en la tercera (modelo II) solamente fueron consideradas las variables significativas del modelo previo.

\section{RESULTADOS}

La edad gestacional fue de $34,4 \pm 4,5$ semanas (2443 semanas) y el peso al nacimiento de $2.195 \pm 944 \mathrm{~g}$ (550-4.350 g). Un total de 159 (89\%) niños recibieron antibióticos, 109 (62\%) ventilación mecánica con una duración media de $13 \pm 15$ días (1-80), 82 (46\%) fármacos vasoactivos y $74(42 \%)$ nutrición parenteral durante una media de $25 \pm 20$ días (2-99). La estancia media en la UCIN fue de $28 \pm 28$ días (2-180 días) y la hospitalización completa de 38,5 \pm 31 días (5-195 días). De los 177 recién nacidos, 129 (73\%) fueron transfundidos, recibiendo 461 unidades (U) con una media de 3,6 $23 \mathrm{U}$ (1-21 U por paciente).

\section{Pacientes que presentaron aumento de la ALT}

La ALT estaba aumentada en $54(30,5 \%)$ pacientes, 46 $(36 \%)$ transfundidos y $8(17 \%)$ no transfundidos $(\mathrm{p}<0,05)$. En la tabla I se muestran los resultados del análisis univa-

Tabla I. Características e intervención terapéutica de los neonatos con aumento de la ALT

\begin{tabular}{lccc}
\hline & ALT aumentada $(n=54)$ & ALT normal $(n=123)$ & 0 \\
\hline Género masculino & $30(55,5)$ & $68(55,2)$ & 1,00 \\
Edad gestacional (semanas) & $34,2 \pm 4,3$ & $34,5 \pm 4,6$ & 0,644 \\
Peso nacimiento (g) & $2249 \pm 1007$ & $37(30)$ & 0,626 \\
Peso $\leq 1.500 \mathrm{~g}$ & $19(35)$ & $83(67)$ & 0,853 \\
Transfusión & $46(85)$ & $2,05 \pm 2,7$ & 0,017 \\
Número transfusiones & $3,85 \pm 4,6$ & $2,08 \pm 2,7$ & 0,009 \\
Número donantes & $3,96 \pm 4,6$ & $47(38)$ & 0,007 \\
Nutrición parenteral & $27(50)$ & $7,6 \pm 14$ & 0,185 \\
Días nutrición parenteral & $17,3 \pm 23,3$ & $72(58)$ & 0,006 \\
Ventilación mecánica & $37(68)$ & $6,2 \pm 12$ & 0,242 \\
Días ventilación mecánica & $12,1 \pm 15$ & $108(88)$ & 0,016 \\
Antibióticos & $51(94)$ & $25,1 \pm 22$ & 0,279 \\
Días UCIN & $34,7 \pm 36$ & $35,6 \pm 26$ & 0,079 \\
Días hospital & $45,2 \pm 40$ & $1(0,8)$ & 0,110 \\
VHG positivo & $14(30)$ & $23(19)$ & 0,0001 \\
VTT positivo & $16(30)$ & 0,782 \\
\hline
\end{tabular}

Las variables cuantitativas están expresadas como media \pm desviación estándar y las cualitativas como número de niños y (\%). 
riante y en la tabla II, los resultados y comentarios del análisis multivariante.

\section{Pacientes que presentaron un aumento de la ALT 2,5 veces el valor normal}

Sólo $20(11,3 \%)$ niños presentaron un aumento de la ALT 2,5 veces el valor normal: $14 \%$ transfundidos y $4 \%$ no transfundidos $(\mathrm{p}=0,106)$. En la tabla III se muestra el análisis univariante y en la tabla IV los resultados y comentarios del análisis multivariante.

\section{Pacientes que presentaron aumento de la AST y de la GGT}

La AST estaba aumentada en $128(72 \%)$ pacientes $(81,7 \pm 128$ U/l; 95\%, IC 59-104 U/l), no había diferen- cias estadísticamente significativas entre transfundidos $93(73 \%)$ y no transfundidos $36(73 \%)$.

La GGT estaba aumentada en $64(36 \%)$ pacientes (136 $\pm 146 \mathrm{U} / 1 ; 95 \%$, IC 95-176 U/1). El aumento se relacionó con la menor edad gestacional $(\mathrm{p}<0,01)$, con el menor peso al nacimiento $(\mathrm{p}<0,05)$, con los pacientes que presentaron aumento de ALT ( $p<0,01)$, con la HPT ( $p<0,05)$ y en el límite de la significación estadística con la transfusión $(\mathrm{p}=0,065)$ y la nutrición parenteral $(\mathrm{p}=0,096)$.

\section{Estudio viral}

No se evidenció ninguna infección por VHA, VHB, VHC, herpes, Epstein-Barr. Un niño no transfundido presentó una infección por CMV a los 5 meses de vida con un incremento de ALT de $75 \mathrm{U} / 1$, que persistió durante un mes. El estudio de la madre resultó negativo para el CMV.

Tabla II. Regresión logística de los neonatos con aumento de ALT

\begin{tabular}{|c|c|c|c|c|c|c|}
\hline & \multicolumn{2}{|c|}{ Modelo 0} & \multicolumn{2}{|c|}{ Modelo I } & \multicolumn{2}{|c|}{ Modelo II } \\
\hline & $\hat{o}$ & $\mathrm{Cl}$ & $\hat{o}$ & $\mathrm{Cl}$ & $\hat{O}$ & $\mathrm{Cl}$ \\
\hline Transfusión & 2,77 & $1,20-6,42$ & 2,44 & $0,88-6,77$ & 2,3 & $0,83-6,20$ \\
\hline > 9 días de VM & 2,84 & $1,41-5,73$ & 1,74 & $0,49-6,14$ & & \\
\hline > 12 días nutrición parenteral & 2,91 & $1,45-5,83$ & 2,06 & $0,54-7,9$ & 2,3 & $1,05-5,18$ \\
\hline > 39 días de UCIN & 1,78 & $0,88-3,61$ & 0,81 & $0,21-3,05$ & & \\
\hline \multirow[t]{2}{*}{ VHG positivo } & 42,7 & $5,44-334,8$ & 45,8 & $5,59-376$ & 46 & $5,64-376$ \\
\hline & \multicolumn{2}{|c|}{176,671} & \multicolumn{2}{|c|}{172,927} & & \\
\hline
\end{tabular}

Comentarios: En el modelo 0 se observa el riesgo calculado (ô) de padecer elevación de ALT y los intervalos de confianza (IC). En el modelo I se observa que las variables estaban fuertemente relacionadas, resultando significativa la infección por VHG [ô $=45,8(5,59-37,6]$. Por último, en el modelo II se comprobó que las únicas variables independientes fueron el tener una infección por el VHG y el riesgo calculado de aumento de ALT fue 46 veces mayor que los pacientes VHG negativos. También se relacionó con un periodo de nutrición parenteral superior a 12 días y en el límite de la significación estadística se encontró la transfusión.

Tabla III. Características e intervención terapéutica de los pacientes que presentaron aumento de ALT 2,5 veces el valor normal (criterio de HPT)

\begin{tabular}{lccc}
\hline & Criterio de PTH $(n=20)$ & No criterio de PTH $(n=157)$ & $p$ \\
\hline Género masculino & $10(50)$ & $88(56)$ & 0,639 \\
Edad gestacional (semanas) & $32,5 \pm 4,8$ & $2230 \pm 930$ & 0,044 \\
Peso nacimiento (g) & $1917 \pm 1002$ & $45(29)$ & 0,163 \\
Peso $\leq 1.500$ g & $11(55)$ & $111(78)$ & 0,018 \\
Transfusión & $18(90)$ & $2,2 \pm 2,8$ & 0,106 \\
No transfusiones & $5,85 \pm 6$ & $2,24 \pm 3$ & 0,012 \\
No de donantes & $5,9 \pm 5,7$ & $61(39)$ & 0,011 \\
Nutrición parenteral & $13(65)$ & $9,18 \pm 17$ & 0,031 \\
Días nutrición parenteral & $21,7 \pm 22,6$ & $93(59)$ & 0,026 \\
Ventilación mecánica & $16(80)$ & $6,75 \pm 12$ & 0,089 \\
Días ventilación mecánica & $18,35 \pm 19,5$ & $140(89)$ & 0,017 \\
Antibióticos & $19(95)$ & $25,7 \pm 25,8$ & 0,698 \\
Días UCIN & $45,9 \pm 37$ & $36,1 \pm 29,4$ & 0.027 \\
Días hospital & $57,4 \pm 41$ & $10(6)$ & 0.036 \\
VHG positivo & $5(25)$ & $31 / 107(29)$ & 0,016 \\
VTT positivo & $8 / 20(40)$ & 0,918 \\
\hline
\end{tabular}

Las variables cuantitativas están expresadas como media \pm desviación estándar y las cualitativas como número de niños y (\%). 
Tabla IV. Regresión logística de los pacientes que presentaron aumento de ALT de 2 a 2,5 veces el valor normal (criterio de HPT)

\begin{tabular}{|c|c|c|c|c|c|c|}
\hline & \multicolumn{2}{|c|}{ Modelo 0} & \multicolumn{2}{|c|}{ Modelo I } & \multicolumn{2}{|c|}{ Modelo II } \\
\hline & $\hat{o}$ & $\mathrm{Cl}$ & $\hat{o}$ & $\mathrm{Cl}$ & $\hat{o}$ & $\mathrm{Cl}$ \\
\hline Transfusión & 3,73 & $0,83-16,73$ & & & & \\
\hline$>2$ transfusiones & 3,04 & $1,18-7,84$ & & & & \\
\hline$>2$ donantes & 3,51 & $1,35-9,14$ & 0,87 & $0,18-4,35$ & & \\
\hline Parenteral & 2,92 & $1,10-7,73$ & & & & \\
\hline > 12 días nutrición parenteral & 5,04 & $1,91-13,2$ & 0,93 & $0,11-7,69$ & & \\
\hline Ventilación mecánica & 2,75 & $0,88-8,61$ & & & & \\
\hline > 9 días ventilación mecánica & 5,42 & $2,06-14,33$ & 2,26 & $0,56-9,10$ & 2,9 & $0,88-9,28$ \\
\hline VHG positivo & 4,9 & $1,48-16,23$ & 3,65 & $0,93-14,3$ & 4,2 & $1,15-15,34^{*}$ \\
\hline Peso nacimiento < 1.500 & 3,04 & $1,18-7,84$ & 1,72 & $0,48-6,13$ & & \\
\hline > 39 días en UCIN & 4,42 & $1,69-11,54$ & 1,93 & $0,39-9,6$ & & \\
\hline \multirow[t]{2}{*}{ > 54 días en hospital } & 3,24 & $1,25-8,39$ & & & & \\
\hline & \multicolumn{2}{|c|}{90,008} & \multicolumn{2}{|c|}{92,70} & & \\
\hline
\end{tabular}

Comentarios: En el modelo 0 se puede observar el riesgo calculado (ô) de padecer aumento de la ALT 2,5 veces el valor normal y los intervalos de confianza. En el modelo I se eliminaron aquellas variables que estaban fuertemente relacionadas, resultando que ninguna fue significativa, la infección por VHG estaba próxima a la significación [ô = 3.65 (0.93-14.34)]. Por último, en el modelo II se comprobó que la única variable independiente fue el tener una infección por el VHG.

El VHG se detectó en 15/177 (9\%) neonatos: 14 fueron ARN-VHG positivos y otro paciente se consideró también infectado, aunque el ARN-VHG fue negativo, ya que durante el seguimiento se observó la seroconversión a anti-VHGE2. De ellos 11/129 (9\%) fueron transfundidos y $4 / 48$ (8\%) no lo fueron, sin que las diferencias fueran estadísticamente significativas.

La figura 1 muestra la epidemiología de la infección por el VHG en los niños transfundidos. Nueve infecciones se produjeron por transmisión parenteral y dos por vía vertical. La tasa de infección por VHG postransfusional fue del 7\% (95\% IC, 3-13\%). Los pacientes con infección postransfusional por VHG recibieron una me-

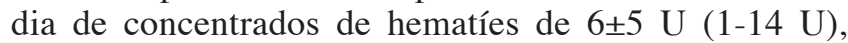
mientras que los pacientes transfundidos y VHG negativo recibieron $3 \pm 3 \mathrm{U}(1-22 \mathrm{U})$, sin que las diferencias fueran estadísticamente significativas. El riesgo calculado de transmisión del VHG por unidad transfundida fue de 1,96\% (95\% IC, 1-3,8\%). Las madres de los cuatro neonatos no transfundidos que fueron ARN-VHG positivo, resultaron ser positivas para el ARN-VHG (transmisión vertical).

El estudio del anti-VHGE2 efectuado en todos los niños fue negativo en todos ellos, excepto en un niño que fue positivo a los 6 meses y negativo a los nueve. En este caso, la madre presentaba anti-VHGE2 y se consideró que se había producido una transmisión pasiva de anticuerpos.

El curso clínico de la infección por el VHG fue leve (Fig. 2). Catorce RN presentaron aumento de la ALT (93\%), pero en sólo 5 (33\%) la ALT fue superior a 2,5 veces el valor normal. El pico máximo de ALT fue de 78 $\pm 46 \mathrm{U} / 1$ y la duración media fue de $3 \pm 2$ meses. Sólo 4 pacientes aclararon el virus a los 18, 36 y 48 meses y en uno se comprobó su seroconversión a anti-VHGE2. Los
11 pacientes restantes permanecieron ARN-VHG positivos aunque la ALT era normal.

El ADN-VTT se estudió en 127 neonatos, de los cuales fue positivo en 39 (31\%): 36/109 (33\%) transfundidos y $3 / 16(17 \%)$ no transfundidos, sin diferencias estadísticamente significativas. En el grupo transfundido, hubo 5 casos de transmisión vertical, ya que las madres fueron también positivas. El resto de las madres fueron negativas y se consideró que la vía de transmisión más probable fue la parenteral. En estos casos no se dispuso de suero de los donantes para comprobarlo. Las madres de los 3 casos del grupo no transfundido fueron ADN-VTT positivo y se consideró que la transmisión había sido vertical. En 7 casos se observó coinfección con el VHG.

El curso clínico de la infección VTT fue asintomática, pero16 niños presentaron un aumento de ALT, de los cuales, 6 estaban coinfectados por el VHG. En 8 (50\%) el aumento de la ALT fue mayor 2,5 veces el valor normal, 3 de ellos estaban coinfectados por el VHG. El pico máximo de ALT fue de $87 \pm 81$ U/1 y la duración media de $4 \pm 3$ meses. Sólo dos niños aclararon el virus a los 6 y 18 meses y el resto continuaron positivos, aunque las transaminasas permanecieron normales.

\section{Estudio serológico de las madres}

En las madres se demostró que 76 (47\%) presentaban anticuerpos anti-CMV-IgG, 46 (28\%) anti-VHA-IgG, 39 (25\%) anti-EBV-IgG, 27 (17\%) anti-VHs-IgG, 11 (7\%) IgG frente toxoplasma, 7 (4\%) anti-HBs, $2(1 \%)$ antiEBV-IgM y un caso $(0,6 \%)$ anticuerpos anti-CMV-IgM. En los dos últimos casos, no se observó ningún tipo de repercusión sobre sus hijos. 


\section{DISCUSIÓN}

Por el momento, no se conoce la prevalencia real de la patología postransfusional en el prematuro y en el neonato, por este motivo se analizaron los factores relacionados con el aumento de la ALT. Los pacientes más graves o nacidos con menor peso requieren más días de ingreso en la UCIN, aunque no todos ellos están sometidos a mayor número de intervenciones terapéuticas, incluida la transfusión.

El $70 \%$ de los neonatos que ingresaron en la UCIN no presentaron aumento de la ALT. El peso o la edad gestacional no se relacionó con el aumento de la ALT; mientras que la transfusión, el número de unidades transfundidas, la estancia en la UCIN, la duración de la asistencia respiratoria y el tiempo de nutrición parenteral, sí se relacionaron con la elevación de la ALT. La mayoría de los niños graves reciben todas estas intervenciones, pero lo que les diferencia es la duración de las mismas; por ello estas variables están relacionadas entre sí. En cambio, la infección por VHG, el tiempo de nutrición parenteral y el hecho de haber recibido transfusiones tienen un valor independiente en la regresión logística. Póstuma y cols. (23), describieron un aumento transitorio de la FA y de la ALT en el 34\% de los recién nacidos después de 4-6 semanas de nutrición parenteral. Otros autores han comunicado la existencia de complicaciones hepáticas en los recién nacidos prematuros y de bajo peso (24-26). En nuestro estudio, los aumentos de la ALT no se relacionaron con el peso ni con el periodo gestacional.

La hepatitis, ampliamente estudiada en el adulto, representa uno de los riesgos de enfermedad postransfusional. El $14 \%$ de los niños transfundidos y el $4 \%$ de los no transfundidos presentaron un aumento de ALT de 2,5 veces el valor normal. El VHG fue responsable sólo de
5 casos, tres de los cuales estaban coinfectados con el VTT. Lo que significa que este aumento de ALT se debe a otros factores, que podrían estar en relación con la enfermedad de base que motivó el ingreso en la UCIN o con otros virus no identificados transmitidos por la transfusión (27). El incremento de AST fue muy frecuente pero también menos específico. Un dato reseñable fue el número de pacientes que presentaron aumentos de la GGT. Esto fue más frecuente en los prematuros de menor peso, relacionado ello posiblemente con cierto grado de colestasis.

Un hallazgo sorprendente es la elevada prevalencia del VTT (31\%). En España, la prevalencia en donantes de sangre sanos es del $14 \%$ y del $76 \%$ en pacientes con hemofilia (28). La transmisión vertical del VHG y VTT es importante y responsable de la infección en los niños no transfundidos y también de algunos transfundidos; por ello es imprescindible el estudio de las madres y de los donantes para interpretar la importancia de la transfusión como responsable de la transmisión de estos virus. La transmisión vertical del VHG y TTV ha sido demostrada por otros autores $(29,30)$ y es más frecuente que la del VHC (31).

En conclusión este estudio demuestra la importancia del control de la ALT y GGT en los niños ingresados en UCIN y su seguimiento, ya que están sometidos a múltiples factores que pueden originar lesiones hepáticas. También hay que resaltar la importancia que tiene el estudio viral en los niños, sus madres y donantes. A pesar de que el VHG no se ha relacionado claramente con cuadros de hepatitis en adultos, en los neonatos estudiados puede justificar aumentos de la ALT. Finalmente en la actualidad las transfusiones son seguras para la mayoría de los virus clásicos, pero es posible la transmisión de agentes virales nuevos como el VHG y el VTT, de escasa patogenicidad. 